\title{
XXI OGÓLNOPOLSKI ZJAZD STUDENTÓW ARCHIWISTYKI Kraków, 24-26 IV 2019 r.
}

$\iint_{\mathrm{o} \text { tym, co ich w archiwistyce i zarządzaniu dokumentacją interesuje, czym }}^{\text {uż }}$ zajmują się w swoich projektach studenckich i doktoranckich, oraz o tym, czego oczekują od współczesnej dyscypliny. Ogólnopolski Zjazd Studentów Archiwistyki po raz drugi zawitał do Krakowa. Organizatorem XXI edycji był Uniwersytet Papieski Jana Pawła II w Krakowie. W tym roku zrezygnowano z hasła przewodniego zjazdu. Organizatorzy, zapraszając do przesyłania propozycji wystąpień, zachęcali: „Nie ograniczamy Was, Drodzy Uczestnicy, hasłem zjazdu. Zabieg ten pozwoli nam spojrzeć na archiwistykę w bardzo szerokim spektrum"1. Co prawda na zróżnicowaną mozaikę archiwistycznych badań spoglądano i przy okazji poprzednich edycji - gdy organizatorzy decydowali się na hasła przewodnie - jednak cel ten i w Krakowie udało się zrealizować. Program konferencji objął bowiem aż 60 referatów wygłoszonych przez 61 przedstawicieli jedenastu ośrodków akademickich i siedmiu instytucji różnego typu.

Uroczyste otwarcie zjazdu nastąpiło 24 IV 2019 r. w gmachu Biblioteki Głównej UPJPII. Spotkanie poprowadzili członkowie komitetu organizacyjnego: Elżbieta Zachara oraz Adrian Cieślik. Głos zabrali m.in. kierownik Katedry Archiwistyki i Nauk Pomocniczych Historii UPJPII Józef Marecki oraz Wojciech Krawczuk, dyrektor Archiwum Narodowego w Krakowie. Po oficjalnej części

${ }^{1}$ Rozpoczynamy zapisy, http://21ozsa.upjp2.edu.pl/node/4 (dostęp dn. 22.05.2019). 
organizatorzy zaprosili do zwiedzania wystawy najciekawszych dokumentów z zasobu Archiwum UPJPII oraz Archiwum Arcybiskupa Eugeniusza Baziaka w Krakowie. Goście wzięli także udział w uroczystym bankiecie. Wieczór uświetnił pokaz rekonstruktorski grupy „Bractwo Lugiów”.

Pierwsze referaty uczestnicy wygłosili 25 IV. Tego dnia odbyły się trzy panele tematyczne: Archiwa - dzieje, zasób i popularyzacja zasobu, Archiwalia w badaniach naukowych oraz Teoria i metodyka archiwalna.

Obrady panelu pt. Archiwa - dzieje, zasób i popularyzacja zasobu otworzyła Dorota Cabaj, przedstawicielka UPH oraz AP w Siedlcach z referatem pt. Organizacja i funkcjonowanie Oddziału Terenowego w Siedlcach Archiwum Państwowego Miasta Stołecznego Warszawy i Województwa Warszawskiego (1964-1976). Następnie głos zabrała Patrycja Chyb z uniwersytetu w Olsztynie, która omówiła stan opracowania zasobu tamtejszej Stacji Naukowej Instytutu Zachodniego „Instytut Mazurski”. Zasób archiwum Państwowego Muzeum na Majdanku przedstawiła słuchaczom Karolina Wasiluk z KUL. Karolina Dzierżawska (UPJPII) wystąpiła następnie z referatem pt. Zarys dziejów i zasób Archiwum Krakowskiej Prowincji Karmelitów Bosych. Drugą część panelu otworzył przedstawiciel UMK Jędrzej Solarz, który przedstawił historię i spuściznę aktową Studenckiego Koła Naukowego Archiwistów przy Uniwersytecie Mikołaja Kopernika. Bartłomiej Konopa - reprezentujący UMK oraz AP w Bydgoszczy - zwrócił uwagę na zagadnienia związane $\mathrm{z}$ archiwizacją Internetu i tym, co znaleźć można w archiwach Webu. Piotr Falkowski (również UMK i AP Bydgoszcz) wygłosił referat pt. Instrukcja dla kierownika Oddziału Bydgoskiego Archiwum Państwowego w Poznaniu. Następnie zabrał głos Łukasz Baranowski (UwB). Referent omówił zbiory Biblioteki Uniwersytetu Wileńskiego oraz przedstawił możliwości ich wykorzystania. Drugą część obrad zamknęła Aleksandra Wajnert z Poznania, która podzieliła się doświadczeniami związanymi z inwentaryzacją starodruków w Archiwum Archidiecezjalnym w Gnieźnie. Trzecią część otworzyła Justyna Pera z Uniwersytetu im. Adama Mickiewicza w Poznaniu z referatem pt. Co o Archiwum Państwowym w Poznaniu mówi jego księga nabytków? Następnie głos zabrała Ewa Bielas (UMK), która przybliżyła działalność Archiwum Państwowego w Płocku w zakresie popularyzacji genealogii. Ostatni referat panelu Archiwa dzieje, zasób i popularyzacja zasobu wygłosiła przedstawicielka gospodarzy Aleksandra Rzońca: Archiwalne gry $i$ gierki - nowe pomysty na popularyzacje zbiorów.

Symultanicznie obradowano w sekcji pt. Archiwalia w badaniach naukowych. Panel otworzyli Aleksandra Pawlak oraz Paweł Gliński (UWM) referatem pt. Korespondencja Jana III Sobieskiego z Mariq - losy i obecne miejsca przechowy- 
wania. Jakub Grodzki (UwB) przedstawił temat Fond 40 w Bibliotece Litewskiej Akademii Nauk im. Wróblewskich $w$ Wilnie. Na akta Wojskowego Sądu Rejonowego jako źródło do badań historycznoprawnych nad orzecznictwem sądowego aparatu represji w okresie stalinowskim spojrzał kolejny referent - Paweł Magiera reprezentujący UPJPII. O najnowszych problemach edytorstwa rozprawiała Monika Kozłowska (UwB), która zaprezentowała temat Elektroniczna czy klasyczna? Edytorstwo źródeł historycznych $w$ dobie cyfryzacji. Po przerwie głos zabrała Anna Makarczyk (UPJPII), która podjęła tematykę nieistniejącej już zabudowy sakralnej dawnego Kazimierza. Podstawę do przygotowania wykładu o kościele św. Jakuba Apostoła stanowiły akta powizytacyjne biskupa Załuskiego z 13 III 1748 r. Jan Bulak (również reprezentujący gospodarzy) wystąpił z referatem pt. Akta wizytacji diecezji żmudzkiej (do 1849 r.) w zasobach Litewskiego Państwowego Archiwum Historycznego (LVIA). W tematyce związanej z aktami kościelnymi pozostaliśmy już do końca drugiej części panelu. Głos zabrali bowiem jeszcze Jakub Dobrzyński (UwB, Źródła do badań genealogicznych w archiwach parafialnych na terenie dawnej Ziemi Bielskiej na Podlasiu, a możliwości badawcze) oraz Mateusz Wojciechowski (UWM, Moźliwości badawcze społeczności Purdy Wielkiej w latach 1942-1772 na podstawie księgi chrztów). Trzecią część panelu otworzył przegląd źródeł traktujących o wsi Kwieciszewo zaprezentowany przez Adama Bigosińskiego z poznańskiego uniwersytetu. Kolejna referentka (Patrycja Mierzyńska z UWM) przygotowała wystąpienie pt. Wilkierze Olsztyna z lat 1568-1696 jako źródto do badań nad społeczeństwem i gospodarka miasta. Problemy w badaniach historii Pomorza Zachodniego były przedmiotem kolejnego referatu: Tomasz Tarasiuk ze szczecińskiego uniwersytetu przedstawił „perypetie pomorzoznawcy” na przykładzie pracy ze Szwedzkim Spisem Katastralnym. Obrady zamknęła Patrycja Krawczyk (UAM) - referentka przedstawiła Ewidencję Ludności Poznania z lat 1870-1931 i możliwości jej wykorzystania w badaniach naukowych.

Trzeci panel pierwszego dnia obrad poświęcono zagadnieniom (bardziej lub mniej) związanym z teorią i metodyką archiwalną. Nad tym, czy dokumentacja nieaktowa w archiwum zakładowym stanowi problem, wyzwanie czy przygodę, zastanawiała się pierwsza referentka - Jagoda Jankowska z toruńskiego uniwersytetu. Następnie głos zabrała Halina Kumur (UP) z wystąpieniem pt. Zmiany $w$ sposobie przechowywania i zarządzania dokumentacja $w$ instytucjach $w$ świetle nowych przepisów. O obiegu dokumentacji zamówień publicznych w Oddziale Regionalnym Kasy Rolniczego Ubezpieczenia Społecznego w Warszawie rozprawiała Katarzyna Grudzień z siedleckiego UPH. Na problem archiwizacji projektu unijnego na przykładzie PAN Biblioteki Kórnickiej zwróciła uwagę Paulina Mi- 
kołajczyk (UAM, AP Poznań). Drugą część panelu otworzył Marcin Smoczyński (UMK) z referatem pt. Wkład Komisji dla Usprawnienia Administracji Publicznej $w$ racjonalizację międzywojennej biurowości polskiej. Kolejnym referentem był Artur Paweł Barcikowski z olsztyńskiego uniwersytetu, który zaprezentował temat Uwagi dotyczace wstępu do Inwentarza archiwalnego zespołu: „Der Provinzionalkonservator der Denkmäler der Kunst und der Geschichte der Provinz Ostpreussen”. Bartłomiej Fiba (UPJPII) podjął próbę analizy porównawczej wybranych polskich i zagranicznych regulaminów i statutów archiwów kościelnych. Kolejny referat (Rozmieszczenie zespołów archiwalnych powiatu ostrołęckiego z lat 1816-1918, a zasada pertynencji terytorialnej. Wybrane aspekty) zaprezentował Adam Andrzej Pawelczyk z uniwersytetu w Olsztynie. Ostatni przed przerwą zaprezentował się Grzegorz Piątek (UAM). Prelegent podzielił się własnymi doświadczeniami związanymi z pracą przy porządkowaniu, opisywaniu i digitalizacji spuścizny o. Tadeusza Alexiewicza. Trzecią część panelu otworzył Adrian Cieślik (UPJPII) z referatem pt. Akta wizytacji kanonicznych $i$ dekanalnych jako cenne źródto historyczne. Pozostałe referaty wprowadziły słuchaczy w problemy współczesnej archiwistyki. Gabriela Kownacka z UP w Krakowie zaprezentowała temat Standaryzacja stron internetowych archiwów państwowych. Monika Cołbecka (UMK, UP) spojrzała na archiwum przez pryzmat instytucji usługowej oraz przedstawiła zakres definicji usług informacyjnych archiwów. Panel zamknął Marcin Krasuski (UPH, AP Siedlce) wystąpieniem pt. Ochrona danych wrażliwych $w$ czytelni archiwalnej.

Na drugi i ostatni dzień obrad (26 kwietnia) przewidziano trzy panele: Archiwa - dzieje, zasób i popularyzacja zasobu, Miscellanea oraz kontynuację czwartkowej sekcji pt. Archiwalia w badaniach naukowych.

Panel Archiwa - dzieje, zasób i popularyzacja zasobu otworzyła Agata Łysakowska-Trzoss (UAM) referatem pt. Ani jedna taśma filmowa nie może ulec zniszczeniu. Osiemdziesiąt lat działalności Międzynarodowej Federacji Archiwów Filmowych. Julia Olejniczak (UAM, AP Poznań) podjęła tematykę archiwum emigracji ze szczególnym uwzględnieniem Archiwum Polskiej Myśli Katolickiej we Francji. Podobny temat zaprezentował kolejny referent - Szymon Jarosiński (UPJPII), który także przybliżył słuchaczom zagraniczną instytucję archiwalną: Archiwum i Muzeum Instytutu Polskiego im. Gen. Władysława Sikorskiego w Londynie. Następnie głos zabrała Dorota Kurek (USz), która wygłosiła referat pt. Ocaleni od zapomnienia. Zasób Visual History Archive USC (University of Southern California) Shoah Foundation oraz jego znaczenie dla badań nad historia społeczności żydowskich $w$ Europie w I poł. XX w. Pierwszą część obrad zamknęła Karolina Strześniewska (UMK, IPN Szczecin), która przybliżyła słuchaczom 
projekt „Archiwum Pełne Pamięci”. Zwróciła uwagę, że „historia to nie tylko wielkie wydarzenia". Po przerwie zaprezentowano trzy referaty. Pierwszy z nich należał do Konrada Balcerka (ŚUW w Katowicach). Autor przedstawił zasób oraz wyzwania stojące przed archiwistami Archiwum Zakładowego i Zlikwidowanych Przedsiębiorstw Państwowych Śląskiego Urzędu Wojewódzkiego w Katowicach. Renata Jońca (UP) zaprezentowała kancelarię Komisji Włościańskiej Wolnego Miasta Krakowa w świetle materiałów archiwalnych znajdujących się w Archiwum Narodowym w Krakowie. Ostatni referat w tej części (Dokumentacja historyczno-konserwatorska w Archiwum Wojewódzkiego Konserwatora Zabytków w Szczecinie na przykładzie akt dotyczacych Sarkofagów Książą Pomorskich) wygłosiła Katarzyna Lisiecka reprezentująca USz.

Wznowione obrady panelu Archiwalia $w$ badaniach naukowych otworzyła Anna Kłoś (UPH) z referatem pt. Źródła archiwalne prezentujące działalność kombatancka na przykładzie materiałów Oddziału Partyzanckiego 34 pp AK Stefana Wyrzykowskiego ps. „Zenon”. Źródła do badań nad okupacją niemiecką w powiecie mińskim przedstawił kolejny referent - Damian Sitkiewicz (UPH). Wiktor Węglewicz z UJ przybliżył słuchaczom źródła do dziejów jeńców i internowanych ukraińskich z Galicji Wschodniej w zasobie archiwów lwowskich. W tematykę historii sportu wprowadził nas Grzegorz Racinowski (USz). Swój referat, który stanowił przyczynek do badań nad inwigilacją polskiego sportu w latach 60. i 70., poświęcił członkom lekkoatletycznego Wunderteamu. Obrady zamknął Bartosz Różanek z UKW wystąpieniem pt. Archiwum Władysława SiłyNowickiego jako źródto do badania życia znanego adwokata.

Paweł Śliżewski (USz) otworzył obrady panelu Miscellanea z referatem pt. Historia i stan zachowania rękopisów historiograficznych dzieł renesansowych kronikarzy pomorskich - Jana Bugenhagena i Tomasza Kantzowa. Oprawy księgi czynności gnieźnieńskiej kapituły katedralnej z II poł. XVI w. były przedmiotem wystąpienia Michała Muraszko z UAM. Następnie referaty wygłosili studenci zainteresowani sfragistyką. Piotr Dyżla (UAM) przedstawił pieczęcie Macieja Radomickiego, Jan Jakub Grabowski (UJ) Ambrożego Grabowskiego, a Weronika Budrewicz (UMK) królowych Wiktorii i Elżbiety II. Obrady wznowiono po przerwie. Jako pierwsza zaprezentowała się Liliana Kasprzak (UAM) z referatem pt. Wyzwania młodego archiwisty - teoria a praktyka. Kamila Siuda (UMK) zaprezentowała temat Egodokumentalność spuścizn Antropologów. Głosy w dwudziestowiecznej dyskusji na temat jednoczenia się polskich bibliotekarzy i archiwistów przybliżył Eryk Magier (UMK). Obrady zakończył referat Elżbiety Zachary (UPJPII): Jak archiwiści czas wolny spędzali, czyli (nie tylko) o przerwach w pracy. 
Końcowym akcentem zjazdu był tradycyjny Sejmik, podczas którego przedstawiciele uczestniczących ośrodków naukowych odnowili Ogólnopolskie Porozumienie Studentów Archiwistyki oraz wybrali organizatora XXII edycji. I tak za rok studenci zawitają do Siedlec w gościnne mury Uniwersytetu Przyrodniczo-Humanistycznego. 